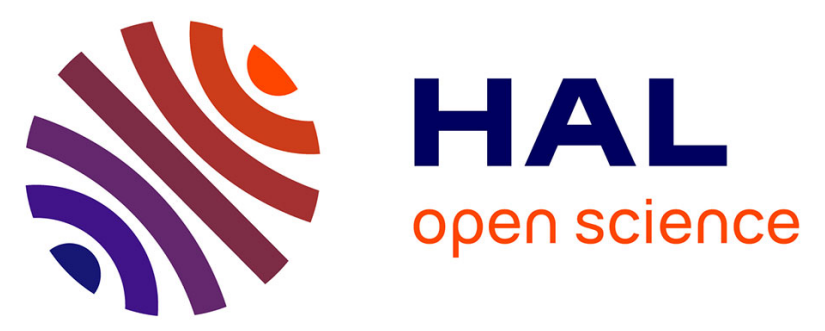

\title{
Shifts in the height-related competitiveness of tree species following recent climate warming and implications for tree community composition: the case of common beech and sessile oak as predominant broadleaved species in Europe
}

Jean-Daniel Bontemps, Jean-Christophe Hervé, Pierre Duplat, Jean-François Dhôte

\section{- To cite this version:}

Jean-Daniel Bontemps, Jean-Christophe Hervé, Pierre Duplat, Jean-François Dhôte. Shifts in the height-related competitiveness of tree species following recent climate warming and implications for tree community composition: the case of common beech and sessile oak as predominant broadleaved species in Europe. Oikos, 2012, 121 (8), pp.1287-1299. 10.1111/j.1600-0706.2011.20080.x . hal00868777

\section{HAL Id: hal-00868777 \\ https://hal.science/hal-00868777}

Submitted on 1 Oct 2013

HAL is a multi-disciplinary open access archive for the deposit and dissemination of scientific research documents, whether they are published or not. The documents may come from teaching and research institutions in France or abroad, or from public or private research centers.
L'archive ouverte pluridisciplinaire HAL, est destinée au dépôt et à la diffusion de documents scientifiques de niveau recherche, publiés ou non, émanant des établissements d'enseignement et de recherche français ou étrangers, des laboratoires publics ou privés. 
Shifts in the height-related competitiveness of tree species following recent climate warming and implications for tree community composition: the case of common beech and sessile oak as predominant broadleaved species in Europe

Jean-Daniel BONTEMPS ${ }^{1}$, Jean-Christophe HERVE $^{2}$, Pierre DUPLAT ${ }^{3}$, Jean-François DHÔTE ${ }^{4,5}$

${ }^{1}$ AgroParisTech, ENGREF, UMR 1092 INRA/AgroParisTech Laboratoire d'Etude des Ressources Forêt-Bois (LERFoB), 14 rue Girardet, 54000 Nancy, France.

2 Inventaire Forestier National, Direction Technique, Château des Barres, 45290 Nogent-surVernisson, France.

3 Office National des Forêts (ONF), Département des Recherches Techniques, Boulevard de Constance, 77300 Fontainebleau, France.

${ }^{4}$ Office National des Forêts (ONF), Direction Technique et Commerciale Bois, Boulevard de Constance, 77300 Fontainebleau, France.

5 INRA, Centre de Nancy, UMR 1092 INRA/AgroParisTech Laboratoire d'Etude des Ressources Forêt-Bois (LERFoB), 54280 Champenoux, France.

Corresponding author: Jean-Daniel BONTEMPS, jdbontemps.agroparistech@gmail.com 


\begin{abstract}
Height growth is a trait that contributes to tree species fitness. How height growth responds to environmental changes may therefore provide indications on species ability to compete and maintain, and on changes in tree community composition. Common beech (Fagus sylvatica L.) and sessile oak (Quercus petraea Liebl.) are the predominant late-successional broadleaved species in Europe, and they differ in their shade-tolerance. On common beech (a shade tolerant species), recent observations across Europe have shown a growth decline during recent climate warming. Because sessile oak is a warmth- and light-demanding species, we therefore hypothesised that it may gain in competitiveness relative to common beech.

We conducted analyses of historical height growth in several regions spanning the distributional range of the two species across a temperate-continental gradient in France. Common beech and sessile oak were sampled in 2 and 4 regions, respectively, and were compared in 2 neighbouring regions. We documented the climatic and nutritional conditions of regional samples. Height growth of 408 trees of various ages was reconstituted from stem analyses. We estimated 20th-century regional chronologies of height growth using a statistical modelling approach that filtered out the effects of ontogeny and site fertility. In regions where both species were sampled, modelled height trajectories were compared at different periods over the 20th century.

Growth chronologies revealed (i) long-term growth rate increases of a magnitude of 50-100\% over 100 years in both species, more acute in the continental domain, (ii) recurrent historical inversions in growth fluctuations between species, (iii) a recent divergence, with growth decline in common beech versus a dramatic growth increase in sessile oak, more acute in colder regions. The analysis of height trajectories indicated a recent reduction in common beech competitiveness relative to sessile oak. In the face of future climate warming, we conclude that increased prevalence of beechoak mixtures may arise.
\end{abstract}

Keywords: tree height, growth, competition, global change, tree communities, composition 


\section{INTRODUCTION}

In the face of environmental change, the ability of tree species to expand or contract will depend on how the key processes of their dynamics respond to the environment, and on the resulting ability to compete with other species. Height growth is one fundamental dimension of the ontogenetic development of trees that reflects adaptive processes such as competition for light and photosynthetic activity (King 1990, Falster and Westoby 2003), and seed dispersal range (Nathan et al. 2001). How height growth is impacted by environmental changes among species may therefore provide preliminary indications on their future relative potential for competition.

Ecosystems have experienced environmental changes for decades, including the rise in atmospheric $\mathrm{CO}_{2}$ concentration (Keeling 1986), atmospheric nitrogen deposition (Holland et al. 2005), or more recently temperature increases (Jones and Moberg 2003). As a consequence, historical changes in forest growth have been widely attested (Spiecker et al. 1996, Boisvenue and Running 2006), including tree height growth (Kahle et al. 2008, Bontemps et al. 2009). In boreal and temperate climates, tree rings provide a reliable basis for reconstructing past tree growth (Cook and Kairiukstis 1990). Stem analysis (Curtis 1964) allows uncover individual tree height growth, based on ring counts at regular height intervals along the stem. Inter-specific comparisons of the past dynamics of height growth, therefore, constitute a privileged means of predicting changes in tree species competitive status.

In order to address the height-related competitiveness of species, it is required to consider species height growth potential. Even-aged stands of single species are homogeneous communities with uniform canopies, where each tree is strongly constrained by its neighbours in access to resources, and competition for light stimulates height growth (King 1990). Although such reaction may depend on species shade-tolerance (Falster and Westoby 2003), direct support can be found in growth comparisons with open-grown trees (Uhl et al. 2006). In such communities, top height represents a measure related to the highest trees of the canopy, and it corresponds to the mean height of a fixed-size population of the largest trees over a fixed forested area (Rennolls 1978, Skovsgaard and Vanclay 2008). This indicator is little dependent on stand density in closed-canopy stands where competition is established (Pienaar and Shiver 1984, Lanner 1985). Under these conditions, top height variations across sites mainly depend on environmental factors, and top height traditionally serves as a proxy for site fertility in forestry (Skovsgaard and Vanclay 2008). Accordingly, many studies have uncovered the predominant role of environmental factors in the variations of of top height, taken at a fixed age - or site index - in various forest contexts (Hunter and Gibson 1984, Chen et al. 2002, Seynave et al. 2008). Therefore, top height growth may serve as a key indicator for investigating the potential competitiveness of species, by using pure even-aged stands as reference communities (Cavard et al. 2011). 
In the present study, we evaluated the case study of common beech (Fagus sylvatica L.) and sessile oak (Quercus petraea Liebl.), as these species are the most common late-successional native broadleaved species in the forested areas of Europe (35 and 12 Mha, respectively, Koeuble and Seufert, 2001, http://fi.jrc.ec.europa.eu) and in France (1.4 and 1.6 Mha, respectively, IFN 2010), where they are regenerated naturally (Hüffel 1926) and are commonly encountered together $(0.74$ Mha in France; Morneau et al. 2008). In addition, common beech is a shade-tolerant species, whereas sessile oak is light-demanding (Bugmann 1996, Hansen et al. 2002, Niinemets and Valadares 2006). Shifts in the relative height growth potential of these species may thus impact extensive forested areas across Europe with non-symmetric consequences; specifically either the increased elimination of sessile oak by common beech or the greater occurrence of mixed communities.

The two species also exhibit distinct responses to climatic factors. Common beech is a continental species (Koeble and Seufert 2001) and it is sensitive to water and temperature stresses (Dittmar et al. 2003, Lebourgeois et al. 2005, Niinemets and Valadares 2006). In contrast, sessile oak is more common on the Atlantic side of Europe (Koeble and Seufert 2001), and it is more limited by temperature (Levy et al. 1992, Bugmann 1996, Lebourgeois 2006). In a context of climate warming, these species may thus show contrasted growth reactions. In common beech, there is consistent arising evidence of a recent growth decline across Europe (Jump et al. 2006, Charru et al. 2010, Bontemps et al. 2011) following decades of increasing growth (Bontemps et al. 2011). In France, this decline was reported more acute in the dryer Atlantic area of its range than in the continental domain. By contrast, long-term and recent growth trends of sessile oak remain undocumented to date, and the question arises as to whether this species may have experienced a similar decline, or have benefited from climate warming.

The objectives of the present study were: (i) to quantify the historical dynamics of top height growth in sessile oak over the past decades, and (ii) to compare both the historical variations in growth rate and the resulting height trajectories of sessile oak and common beech, at different dates over the 20th century, to infer changes in their relative competitive potential. In line with the species response to the abiotic environment, we tested the hypothesis that sessile oak and common beech may show contrasted historical variations in height growth, and that sessile oak may benefit from climate warming, with a relative gain in competitiveness relative to common beech. We considered common beech and sessile oak in France, where their distribution overlap. To complement the documented trends on common beech in two regions of its distribution (Bontemps et al. 2011), we formed four regional sessile oak samples along a temperate-continental gradient. To investigate the relative competitiveness of these species, two samples of each species were chosen as close as possible in space. We used a methodology aimed at extracting historical variations in top height 
growth, based on retrospective growth data obtained from stem analyses. The sampling design relied on site-paired young/old forest stands for an efficient separation of the effects of ontogeny and history, while ensuring comparable site fertility between in the two stand generations (Bontemps et al. 2009).

\section{MATERIALS}

\section{Sampling and collection of environmental data}

Species were sampled in their distributional ranges across plains and hills. These distributions appear to be distinct in space: common beech occurs along the Atlantic area and in north-eastern France, including mountains, while sessile oak occurs in more southern areas (Figure 1). Nevertheless, both species overlap all along their common distributional margins. We sampled 4 regions in the distributional range of sessile oak in northern France (samples O1 to O4). Samples O1 (Normandy, NW France) and O2 (Lorraine and Vosges hills, NE France) were selected to supplement the Beech samples (Bontemps et al. 2011) located in the plains of Normandy/Picardy (B1) and in Lorraine and Vosges hills (B2). Samples O2 and B2 were spatially intermixed. Oak sampling extended towards its southern and western limits to screen possibly differing trends at warmer sites, in the Loire Valley (O2) and in the Centre region (O3). Species distribution and sampled sites are mapped in Figure 1. The mean sample elevation ranged from 120 to $370 \mathrm{~m}$ (Table 1). Sample B2 was located at a mean elevation $65 \mathrm{~m}$ higher than sample $\mathrm{O} 2$.

In each region, we applied the paired-plots method (Bontemps et al. 2009) to form the sampling design, pairing young/old neighbouring stands (around 75/150 years) growing in sites of the same fertility conditions. Assuming the height growth curve is available in each stand (see growth data collection below), the sampling strategy is as follows: (1) stands of differing ages are sampled to disentangle the effects of ontogeny and calendar year on growth, as this allows compare the growth of stands of the same developmental stage between different dates, i.e. to measure a temporal growth change at constant stage, (2) two stands of different ages (paired stands) are sampled in the same sites, to avoid confounding of factors between site and calendar year. This implies that the measure of temporal growth changes is performed in constant site conditions, and it is made possible over the entire range of developmental stage covered by the two stands, (3) a collection of such paired-stands is sampled in varied site conditions encountered in the study region, to estimate a mean regional growth chronology, depending as less as possible on particular site conditions. This between-pair variation of site is accounted for in the modelling approach.

While 15/14 pairs were sampled in B1/B2 regions, 10 stand pairs/region were targeted for sessile oak (Table 1), including some older sessile oak stands sampled in Duplat and Tran-Ha (1997). The identity of site fertility within pairs was assessed from an in situ control of topography, parent rock, 
and soil (depth, texture and stoniness), completed by soil water and nutrition indicators obtained from soil analyses. These included soil water capacity at $1 \mathrm{~m}$ depth (SWC), soil pH, base saturation rate (BS), C:N ratio, and phosphorus content, up to $30 \mathrm{~cm}$ depth (Table 1). Paired stands of sessile oak were sampled in very close proximity to each other (from 210 to $390 \mathrm{~m}$ ). Accordingly, no systematic between-generation difference in these indicators was detected based on paired $t$-tests (not presented, see Bontemps et al. 2009, 2011, for common beech).

For each sampled pair, we also extracted monthly mean climatic indicators (period 1961-1990) from the AURELHY model at a 1-km resolution (Bénichou and Lebreton 1987). These included precipitation $(\mathrm{P})$ and mean temperature $(\mathrm{Tm})$ averages. Based on temperature and solar radiations (Piedallu and Gégout 2007), monthly Turc potential evapo-transpirations (PET) were computed (Turc 1961). Monthly water balances (P - PET) and soil water deficits (SWD, Lebourgeois et al. 2005) were computed from a combination of P, PET and SWC.

The mean annual temperature was around $10{ }^{\circ} \mathrm{C}$ in all samples (Table 1). However, the mean annual temperature and the mean temperature of the growing season for the southernmost samples $(\mathrm{O} 2$ and O3) were $1{ }^{\circ} \mathrm{C}$ higher than in the northern samples. Annual precipitation ranged between 700 and $900 \mathrm{~mm}$ across all samples. In all samples, except sample O2, the annual water balance (P-PET) was positive. Soil water capacity was over $120 \mathrm{~mm}$ on average in all samples, resulting in average soil water deficits at the end of August of below 40mm (sample B1). Samples were mostly located on acidic soils, and soil $\mathrm{pH}$ was on average below 5 units. Base saturation rate remained moderate (below 50\% in all samples). Soil C:N ratio reflected low (samples O1, O3, O4, B1) to fair (O2, B2) mineralisation conditions. We identified a W-E gradient of nutritional resources from soil $\mathrm{pH}, \mathrm{C}: \mathrm{N}$ ratio, BS, and phosphorus content. The samples used for the species comparison of growth (O1/B1 and $\mathrm{O} 2 / \mathrm{B} 2$ ) revealed remarkably similar average water and temperature indicators (Table 1). Only in the western region, a lower SWC in B1 than in O1 resulted in a SWD higher by $25 \mathrm{~mm}$ at the end of August. In both western and eastern regions, beech plots were located in better average soil conditions than oak plots, as evidenced from the $\mathrm{pH}, \mathrm{BS}, \mathrm{C}: \mathrm{N}$ ratio, and phosphorus content.

Three annual 20th-century chronologies of both mean temperature and precipitation anomalies were built for samples $\mathrm{O} 1 / \mathrm{B} 1, \mathrm{O} 2 / \mathrm{B} 2$ and $\mathrm{O} 3 / \mathrm{O} 4$, as averages of 12 precipitation and 11 temperature centennial homogenised climatic series covering the samples (Supplementary material Fig. A1). Climate warming occurring since the mid 1980s, in particular, was clearly depicted in both temperature chronologies.

\section{Collection of growth data}

Top height was defined as the mean height of the 100 largest trees in diameter per hectare. Accordingly, we sampled 5 dominant trees were sampled in 0.06-ha circular plots in each stand, to obtain an unbiased local sample of the dominant tree population (Pierrat et al. 1995). We cut the $1^{\text {st }}$, 
$3^{\text {rd }}$ and $5^{\text {th }}$ thickest trees to reduce the sampling cost. In total 408 trees were cut. Height trajectories of each tree were reconstructed using stem analysis (Curtis 1964). We sampled discs at regular heights along the stem up to the terminal bud, around every 4 meters in the lower part of the stem and every 2 meters in the upper part, and in the crown. We sawed the first disk at a height of $1.30 \mathrm{~m}$ for common beech, and of $0.30 \mathrm{~m}$ for sessile oak. On each disc, we performed ring counts to date each individual height record. We calculated the top height curve as the average of the 3 individual curves after date matching. In sessile oak, we identified some polymorphism in the early portion of height curves (Duplat and Tran-Ha 1997), and removed the first increment (0.30 m-4.30 m). Mean heights were calculated every 7.8 and 10.3 years on average (SD: 4.6 and 5.0 years) on common beech and sessile oak, respectively (Table 1). In sessile oak, one plot-pair was discarded (sample O3, Table 1), as the height pattern indicated a coppice-regenerated origin in the older stand. The height curves for sessile oak are shown in Figure 2, and in Figure 2 of Bontemps et al. (2011) for common beech.

\section{MODELLING APPROACH}

\section{Model formulation}

Both developmental stage, local site fertility and historical changes in environmental factors affect growth. Estimating historical growth changes therefore requires filter out the effects of developmental stage and site fertility, which is permitted by the present sampling design. Accordingly, the top height increment was analysed as a composition of the effects of developmental stage, site fertility conditions, and calendar year. Developmental stage and permanent site fertility conditions were represented by top height and a site parameter specific to each stand pair, respectively. The model was formulated as a multiplicative composition (Garcia 1989) in continuous time:

$$
d H_{0} / d t=f_{2}\left(t-t_{\mathrm{b}}\right) \mathrm{S}_{\mathrm{b}} f_{1}\left(H_{0}\right)
$$

where $H_{0}$ is top height, $t$ is the variable for time, $f_{2}$ is the historical change measured from a base date $t_{\mathrm{b}}$ (hence $f_{2}\left(t_{\mathrm{b}}\right)=1, \mathrm{~S}_{\mathrm{b}}$ is the site fertility parameter representing the effect of site conditions at the reference date $t_{\mathrm{b}}$ (hence $f_{2}$ appears as a modifier of site fertility over time), $f_{1}$ is a sigmoid growth equation, representing the effect of developmental stage. To account for decennial variations in growth rate over time, $f_{2}$ was represented by a cubic spline polynomial (Table 2), with the year 1900 taken as the base date $\left(t_{\mathrm{b}}\right)$. Spline internodes of 20,15 and 10 years were successively tested. Bontemps et al. $(2009,2011)$ provide an in-depth justification of the model formulation and the final model fits obtained for common beech. We here provide further details regarding sessile oak, for which variants concern the growth equation used.

Height trajectories in sessile oak did not show any strong slowing in later stages (Figure 2). We thus 
tested the two following growth equations for function $f_{1}$ : (i) the Korf equation (Zeide 1993) whose corresponding trajectory shows slow convergence towards the asymptotic height, and (ii) an original growth equation where height asymptotically behaves as a power function of time of exponent <1, and denoted AP (for "asymptotic power" function). Both equations generate sigmoid trajectories. These are presented in the Supplementary material Appendix 2, Eqs. A1 and A2.

\section{Statistical methodology}

Eq. 1 was integrated with respect to time, since the increments to be fitted were pluri-annual (time interval denoted $\left[t_{\mathrm{i}}, t_{\mathrm{i}+1}\right]$ where $t_{\mathrm{i}}$ is the time position associated to the $\mathrm{i}$-th height record resulting from stem analysis). From the equivalent differential form:

$$
1 / f_{1}\left(H_{0}\right) d H_{0}=\mathrm{S}_{\mathrm{b}} f_{2}\left(t-t_{\mathrm{b}}\right) d t
$$

integration leads to:

$$
F_{1}\left(H_{0}\left(t_{\mathrm{i}+1}\right)\right)-F_{1}\left(H_{0}\left(t_{\mathrm{i}}\right)\right)=\mathrm{S}_{\mathrm{b}}\left(F_{2}\left(t_{\mathrm{i}+1}\right)-F_{2}\left(t_{\mathrm{i}}\right)\right),
$$

where $F_{2}=\int f_{2}(u) d u$ and $F_{1}=\int 1 / f_{1}(v) d v$, and $u$ and $v$ are dummy variables for integration, providing the following statistical model:

$$
H_{0}\left(t_{\mathrm{i}+1}\right)=F_{1}^{-1}\left(F_{1}\left(H_{0}\left(t_{\mathrm{i}}\right)+\mathrm{S}_{\mathrm{b}}\left(F_{2}\left(t_{\mathrm{i}+1}\right)-F_{2}\left(t_{\mathrm{i}}\right)\right)\right)+\varepsilon\right.
$$

where $\varepsilon$ stands for the model residuals.

Eq. 2 was fitted as a non-linear mixed-effects models (Lindström and Bates 1990) where local parameters (here $S_{b}$, the effect of site common to a given stand pair) are considered as realisations of random variables whose parameters are estimated in the procedure (mean, and variance $\sigma_{S}$ ). Parameter $S_{b}$ and the residual error $\varepsilon$ were assumed Gaussian and independent (Lindström and Bates, 1990). The model was fitted by maximum likelihood using the nlme function of S-PLUS software (version 2000). In the case of Eq. A2, no formal solution exists for $\int 1 / f_{1}(v) d v$, and we used the Runge-Kutta 4 numerical method of integration, implemented in a sub-function called by nlme. Nested models were compared using the likelihood ratio test (LRT, Pinheiro and Bates 2000). Models based on different equations were compared with the AIC. The AP growth equation was found significantly more accurate than the Korf equation and was retained. The 10-year internode for the spline function of calendar date also provided best fits. Steps of the statistical model elaboration are detailed in Supplementary material Appendix 3. Summary statistics and parameter estimates for the final model retained are shown in Table 2.

\section{Shift in the relative competitive status of tree species}

Historical changes in growth rate $\left(f_{2}\right.$, Eq. 1) modify height trajectories of species over time. We assessed changes in the relative competitive status of common beech and sessile oak over the 20th century based on samples O1/B1 and O2/B2. Families of top height curves were computed up to an 
age of 100 years for each species, and they were compared at 3 different periods in time: under the virtually permanent environmental conditions of the reference years (i) 1900 and (ii) 2000, using constant growth rates $\mathrm{S}_{\mathrm{b}}$, and $f_{2}$ (2000) $\mathrm{S}_{\mathrm{b}}$ (Eq. 1), respectively, (iii) under site conditions progressively shifting from 1900 to 2000, based on the estimation of $f_{2}$ (Table 2 and Figure 3) and by considering stands growing from 1900 onwards. Three curves were computed for each species and year/period of comparison: the height curve expected in the average site conditions of each sample (estimated mean of parameter $S_{b}$ ), and lower and upper height curves representing the extreme site conditions of each region. We defined these curves using the quantiles 0.025 and 0.975 of the Gaussian distribution of parameter $S_{b}(95 \%$ of the range in site conditions, Table 2$)$.

\section{RESULTS}

In sessile oak, the younger stands were found on average taller than the older ones in samples $\mathrm{O} 2$ to O4: the sample averages of pair-wise top height differences taken at the age of the younger stands amounted to $+3.3 \mathrm{~m}(\mathrm{O} 2,68$ years, $\mathrm{p}<0.001),+3.1 \mathrm{~m}(\mathrm{O} 3$, comparison age: 90 years, paired $t$-test: $\mathrm{p}<0.01),+2.8 \mathrm{~m}(\mathrm{O} 4,93$ years, $\mathrm{p}=0.01)$. In sample $\mathrm{O} 1$, no apparent change over time was obvious (see Supplementary Material) and the difference was not significant. In the northern samples (O1 and $\mathrm{O} 2)$, height curves were found strongly singular, as they showed a second inflection in their extremities. This feature suggested very strong growth acceleration at a recent period. We did not observe this pattern in the southern samples (O3 and $\mathrm{O} 4)$.

Chronologies of height growth in sessile oak are shown in Figure 3, together with the top height increments filtered out from the effects of developmental stage and site. Consistent with tests of pair-wise height differences, strong long-term positive changes in growth rate were identified in all samples, except for O1, with clear regional differences. Fluctuations in growth rate were observed over the century and were synchronous between samples. In sample O1, where no change was apparent in the raw data except for a recent inflection in growth curves, the chronology displayed no significant change before the years 1980s. However, the recent increase in growth was very acute, whereby the end-century growth rate was of a twice as high magnitude as in the reference year 1900. In samples O2 to O4, we reported a fairly similar course of changes. A first acceleration of growth was depicted in the 1950s to 1960s, following a negative anomaly of growth in the early 1940 s, with increases ranging from $+30 \%$ to $+50 \%$ relative to 1900 . In the 1970 s, a negative anomaly in growth rate was observed in sample $\mathrm{O} 1$, which was more limited in samples $\mathrm{O} 2$ to $\mathrm{O} 4$. The second acceleration was observed in the 1980s. The growth rate increase culminated to a comparable magnitude of $80 \%$ in samples $\mathrm{O} 3$ and $\mathrm{O} 4$ and up to a magnitude of $120 \%$ in sample $\mathrm{O} 2$, thus representing the highest increase among all 4 samples.

We compared the sessile oak and common beech chronologies of height growth in the regions 
where both species were sampled (samples O1/B1 and O2/B2) in Figure 4. Common features were found between the 2 species: (i) the highest changes in growth rate were observed in the second half of the 20th century, starting in the 1940s for sessile oak and around a decade later in common beech, and (ii) the historical change in growth rate was much more acute in the north-eastern region (O2/B2). The order of magnitude for this change was around $+50 \%$ to $60 \%$ at the end of the $1980 \mathrm{~s}$, and twice as low in the north-western region (O1/B1). These chronologies also pointed out to fluctuations that were specific to each species, highlighting patterns of divergence. In the end 1940s, a reduction in growth rate was observed in common beech, whereas sessile oak growth started increasing. The 1970-1980s was the most favourable growth period for common beech over the 20th century, but it corresponded to a slowing $(\mathrm{O} 2)$ or even decrease $(\mathrm{O} 1)$ in growth rate for sessile oak. We observed the most striking divergence in the recent period (1980-2000), with a decline in the growth of common beech following decades of increase versus an unprecedented increase the growth of sessile oak. This increase neighboured $80 \%$ over that period in sample $\mathrm{O} 1$ and $45 \%$ in sample $\mathrm{O} 2$. In sample $\mathrm{O} 1$, it occurred after decades with no clear trend.

Figure 5 shows comparisons of species-specific families of height curves in samples O1/B1 and O2/B2 for reference years 1900 and 2000, and over the 20th century. Preceding the growth changes highlighted over the 20th century, common beech showed a clear trend to grow faster than sessile oak (Figure 5a), in particular above the age of 40 years. Before that age, mean height trajectories were fairly similar. However, at younger age, sessile oak showed a slightly greater growth than common beech. In addition, the height range induced by extreme site fertility conditions estimated in each region reached a maximum $10 \mathrm{~m}$ for stands between 50 and 100 years old. As a result of these site variations, the height domains covered by the 2 species showed some overlap. It was maximal for ages of around 30-50 years (around $8 \mathrm{~m}$ ), and declined to around $5 \mathrm{~m}$ at 100 years old. Also, the overlap was more restricted in the north-western $(\mathrm{O} 1 / \mathrm{B} 1)$ region than in the north-eastern (O2/B2) region. This overlap suggested that sessile oak trees located in the best species site conditions could grow faster that common beech trees located in their worst site conditions.

Height trajectories of species undergoing progressive growth change over the $20^{\text {th }}$ century (Figure $5 b)$ showed a discernible but moderate relative impact of growth fluctuations (Figure 4). Where late growth diverged between species (Figure 5a), a convergent pattern was observed following recent opposite fluctuations. In sessile oak, we identified a spoon-shaped pattern in late growth, indicating the ability of the model to simulate the singular inflection point of the late-growth phase already observed in the data (Supplementary Material). In samples O1/B1, where changes were moderate up to a recent period, no strong change was identified. In samples O2/B2, strong increases in growth resulted in much straighter trajectories, whereby growth slowing was particularly imperceptible up to 100 years, and in a shift of up to $5 \mathrm{~m}$ in both species at 100 years. 
The divergence in growth between these species over the period 1980-2000 (virtual conditions of 2000, Figure 5c) was found strongly detrimental to common beech compared to sessile oak. Remarkably, the average height growth was now greater in sessile oak than in common beech in the north-eastern region (O2/B2), for stands up to 50 years old. At an age of 100 years, the average top height was only around 3 meters higher in common beech than in sessile oak. The overlap between height domains was also increased. For stands of 40-60 years, the height domains covered by the 2 species were undistinguishable, and the overlap remained above $7 \mathrm{~m}$ at 100 years. In the northwestern region $(\mathrm{O} 1 / \mathrm{B} 1)$, the relative shift between species was even more acute, as the average height trajectory in sessile oak was above that of common beech all over the considered age interval. Up to an age of 18 years, the height domains of the 2 species did not overlap, indicating that greater height growth in sessile oak remained consistent regardless of site fertility conditions. The overlap increased until an age of 100 years, where the 2 height domains were similar.

In summary, both species have undergone positive height growth trends over the 20th century, thus keeping pace with each other regarding their relative height growth potential. However, sessile oak growth has been more strongly favoured than common beech growth following recent historical growth changes. Therefore, the north-western region is illustrative of a potential inversion in species precedence with respect to height growth and competition for light.

\section{DISCUSSION}

\section{Top height growth as an indicator of species fitness}

Positive changes in forest growth over the past decades have been widely reported for temperate and boreal species (Spiecker et al. 1996, Boisvenue and Running 2006). However, studies on height growth remain very limited, as sampling this dimension of growth by retrospective methods remains costly (Kahle et al. 2008). Where focus has been given at primary growth, top height - the mean height of the most vigorous trees in a pure and even-aged tree community - is most often used as a proxy for the total production of a stand since its origin (Kahle et al. 2008, Bontemps et al. 2009), which is known as the Eichhorn's rule (Skovsgaard and Vanclay 2008). Yet, the adaptive role of height growth in featuring inter-species competition for light, and the potential consequences of temporal changes in this trait for the co-existence and replacement of species remains uncovered. In addition, analyses of height growth changes (Elfving and Tegnhammar 1996, Kiviste 1999, Messaoud and Chen 2011) rely on site index - or top height at a given fixed age - which can be computed from a single age-height observation (Garcia 2006). While site index is of interest for uncovering mean growth-environment relationships (Seynave et al. 2008, Watt et al. 2010), this indicator however cannot reveal the dynamics of height growth over time, a key aspect for assessing species ability to compete over a range of several decades. The fact that very few studies have 
proposed unambiguous dynamical insight into growth variations (such as Visser and Molenaar 1990, Dhôte and Hervé 2000, Bontemps et al. 2009) certainly accounts for this gap of knowledge.

In the present study, we focused on common beech and sessile oak, as these are the most common late-successional broadleaved species in the forested areas of Europe, and they exhibit different preferences for climatic factors. Hence, we hypothesised that these species would differ in their historical growth fluctuations following environmental changes, implying possible shifts in their competitiveness. Because common beech is shade tolerant and sessile oak is light demanding (Bugmann 1996, Hansen et al. 2002), the potential consequences of these shifts are not symmetric.

\section{Sampling design of height growth and modelling approach}

The method we developed (Bontemps et al. 2009) uses paired-stands of different age classes growing in the same permanent site conditions, to avoid site-related biases. We aimed for the sets of pairs to encompass the variety of site conditions within a region. The statistical modelling approach disentangles the respective roles of ageing, site, and history in height growth rate, for the extraction of historical growth chronologies. The use of mixed-effects models (Lindström and Bates 1990) permits an efficient quantification of the effect of site, with an estimated population standard deviation around the average maximal growth rate. This allowed us to derive the lower/upper boundaries for height trajectories within a given region (Figure 5).

In sessile oak, the reported changes are of similar magnitude to those estimated for common beech (Figure 4), and they even reach $+100 \%$ when the decade 1990-2000 is included, implying a doubling in growth rate over the last century. Because the latter order of magnitude is high, we focused on the growth modelling assumptions. In sessile oak, the slowing of growth at later developmental stages remains tenuous over the age ranges considered (Supplementary Material). We thus paid a specific attention to the selection of growth equations, including: (i) an asymptoticsize sigmoid growth curve using the Korf equation which has a particularly slow convergence, and (ii) a sigmoid growth curve with an inverse-parabolic branch of time, where the asymptote assumption is therefore relaxed. The latter equation proved more accurate than the Korf equation in fitting the data, even after a growth trend was taken into account. This indicated an intrinsically low slowing of height growth in sessile oak. Because the asymptote assumption was relaxed, the $+100 \%$ magnitude of trend reported for sessile oak over a century cannot be overestimated.

\section{Historical trends in height growth and their interpretation}

In common beech, positive changes in growth rate of a magnitude of $30 \%$ and $60 \%$ over the 20th century were estimated in samples B1 and B2, respectively (Figure 4). The growth increases observed in the second half of the 20th century were interpreted in Bontemps et al. (2011) as 
resulting from a main effect of nitrogen deposition onto nitrogen-constrained forest stands, which is in accordance with the nitrogen limitation demonstrated on height growth (Seynave et al. 2008). This result also agrees with short- (Solberg et al. 2009) and long-term (Nellemann and Thomsen 2001, Kahle et al. 200) observations of forest growth, and with retrospective process-based modelling explorations (van Oijen et al. 2008), at a European scale. We inferred that lower growth increases in sample B1 were due to on locally higher nitrogen and water constraints. In addition, the decennial decreases in height growth observed in the 1940s and 1990s parallel successive periods of co-occuring positive temperature/negative precipitation anomalies in the years 1943-1949, and strong positive temperature anomalies in the years 1987-2000 (Figure 2), which is in agreement with the reported negative sensitivity of height growth to summer temperatures (Seynave et al. 2008) and the reported positive sensitivity to water availability (Seynave et al. 2008, Albert and Schmidt 2010). Studies on radial growth also recorded similar positive effects of summer water availability (Lebourgeois et al. 2005, Dittmar et al. 2003) and negative effects of temperatures (Dittmar et al. 2003). Following the unprecedented climate warming reported since the mid-1980s in world and French temperature chronologies (Jones and Moberg 2003, Moisselin et al 2002, Figure 2), a general decline in the growth of common beech has been demonstrated in both Mediterranean (Jump et al. 2006, Piovesan et al. 2008) and temperate (Charru et al. 2010, Bontemps et al. 2011) areas of Europe.

Until the present study, literature has not been available about past growth increases of sessile oak in Europe, and associated environmental interpretation. The positive impact of higher nitrogen availability, resulting from nitrogen deposition (Croisé et al. 2005 in France) over the past century is again plausible, as a strong nutritional control on height growth has also been evidenced for sessile oak in Bergès et al. (2005) and Seynave et al. (comm. pers., using the same approach as Seynave et al. 2008 on common beech). In the present study, we further identified a very significant negative effect of soil C:N ratio (positive effect of $\mathrm{N}$ availability) on variations in maximum growth rate $\left(\mathrm{S}_{\mathrm{b}}\right)$ over samples $\mathrm{O} 1$ to $\mathrm{O} 4$ ( $\mathrm{p}<0.001$, partial $\mathrm{R} 2=22 \%, n=39$ pairs). The growth decrease shown in the 1970s (Figure 3) is consistent with negative pointer years identified in Lebourgeois et al. (2006). This decline parallels a long period of low negative temperature anomalies (several successions over 1960-1980, Figure 2), and a succession of strong negative precipitations anomalies, starting from 1968-1970 depending on the sample, with a minimum in 1976. Both temperature and precipitation anomalies are however less intense in sample O1 (Figure 2). Growth declines evident in the early 1940s also parallel a strong pluri-annual negative anomaly of temperature. The recent (1980-2000) growth increases reported here (Figure 3) are concomitant to the recent warmer period. Both events are consistent with temperature limitation in sessile oak. While there are reports of little or no effect of water availability on height (Bergès et al. 2005) and radial (Lebourgeois et al. 2004) 
growth, a temperature limitation has frequently been acknowledged (Levy et al. 1992, Seynave et al. comm. pers., Lebourgeois et al. 2004, Diaz-Maroto et al. 2006, Lebourgeois 2006). We also provide direct support of this limitation hypothesis. First, we found a significant positive effect of mean temperature of the growing season (from May to August) on site estimates of maximum growth rate $(\mathrm{p}<0.01$, partial $\mathrm{R} 2=11 \%, n=39)$. Second and remarkably, higher recent growth increases were observed in the northernmost samples (O1 and O2, Figure 3), where the mean 19611990 temperature of the growing season was by $1{ }^{\circ} \mathrm{C}$ lower than for samples O3 and O4 (Table 1).

Tree growth stimulation by increasing atmospheric $\mathrm{CO}_{2}$ is not in contradiction with the positive 20th-century growth trends reported in both species. It could however not be further tested from a spatial correlation analysis, as $\mathrm{CO}_{2}$ concentration shows a strong spatial homogeneity. The $\mathrm{CO}_{2}$ fertilisation of forests has been hypothesised from long-term observation (Lamarche et al. 1984), and is supported by some Free Air $\mathrm{CO}_{2}$ Enrichment experiments (Norby et al. 2005). However, this enhancing $\mathrm{CO}_{2}$ effect has also been challenged by observation (Jacoby and d'Arrigo 1997) and experiment (Körner et al. 2005), and it remains debated (Koutavas 2008, Frank et al. 2009). As emphasised in recent reviews, $\mathrm{CO}_{2}$ fertilisation may be strongly context-dependent, preferentially occurring in nitrogen-rich (Nowak et al 2004, Luo et al. 2004), and warm and semi-arid (Huang et al. 2007) contexts.

\section{Shifts in the relative competitiveness of sessile oak and common beech}

For regions where both common beech and sessile oak were sampled (O1/B1 and O2/B2), mean height trajectories and their lower/upper boundaries were computed for up to 100 years: (i) in the fixed virtual site conditions of 1900 and 2000 (Figures 5a,c), and (ii) in gradually shifting site conditions over the twentieth century (Figure 5b) as a consequence of the reported historical variations (Figure 4).

In both regions (Figure 5a), height growth was, on average, higher in common beech than in sessile oak above an age of about 50 years, with an average difference of around $7 \mathrm{~m}$ at 100 years. Because sessile oak is a light-demanding species, this result indicates a mean trend towards the domination of mixed-communities by common beech. This seems in accordance with the restricted overlap of these species distributions (Figure 1). The effect of site variations also resulted in a height range of typically $10 \mathrm{~m}$ between the extremes trajectories of a each species ( $7 \mathrm{~m}$ for sessile oak in sample O1), a magnitude that is similar to the average difference between species. While we cannot fully exclude situations where sessile oak is likely to grow faster than common beech, height growth, however, shows analogue variations with local site factors related to soil nutrition and soil water capacity (Bergès et al. 2005, Seynave et al. 2008). The scenario with gradual modification of height trajectories over the past century (Figure $5 b$ ) is not radically different, with moderate or recent 
changes in samples O1/B1 (Figure 4), and changes of comparable magnitude in samples O2/B2. Height trajectories (Figure 5b) also revealed the footprint of growth variations that occurred in the second half of the century (Figure 4). Therefore no relative shift was induced (but an absolute shift of maximum $5 \mathrm{~m}$ was detected), and the growth comparative advantage of common beech on sessile oak, as it is inferred from height growth, may not have changed much over decades. However, following the recent divergence in height growth rate of the 2 species, and the dramatic increase in sessile oak growth over recent decades (Figure 4), a shift in their relative competitiveness is inferred under the conditions of the late 20th century (Figure 5c). Height growth in sessile oak of up to 50 years in age is consequently higher in both regions. While the average growth advantage of common beech is reduced but conserved at later ages in samples O2/B2, sessile oak is predicted to grow taller across the whole range of age comparison in samples O1/B1. Because common beech is a shade-tolerant species, this does not indicate any possibility of elimination by sessile oak. However, this finding clearly implies that the co-existence of these two species will be on average more frequent, if warming is not transient and these differences are maintained. Investigations in mountain and continental areas of Central and Eastern Europe, where these species distributions also overlap, would bring broader insight into the increased competitiveness of sessile oak. In addition, in-depth modelling of climate-growth relationships in these two species is now required to generate explicit spatial quantitative predictions of these shifts on the forested areas, in France and Europe.

\section{Conclusions}

We reported strong increases in the height growth of common beech and sessile oak over the 20th century. In addition, growth variations of opposite sign are identified all along that period. These were associated with climate anomalies in the 1940s and since the 1990s, whereby the increase/decrease in height growth of sessile oak/common beech, respectively, corresponded to singular warm periods, of which the recent unprecedented warming. These observations are in line with the respective autecological response of these species.

The comparison of height trajectories at distinct time points (1900 and 2000, and over the 20th century), and in regions where species were sampled in close proximity, further supported an inversion in the height-related competitiveness of these species, in favour of sessile oak. As a major outcome of this contribution, the impact of environmental change has thus been of a strong enough magnitude to induce such shifts. We hypothesise that the relative competitiveness of sessile oak will continue to increase over the coming decades, as climate gradually becomes warmer (IPCC 2007). We also infer an increased occurrence of mixed-species communities of common beech and sessile oak trees, as common beech is a shade-tolerant species. A spatial quantitative assessment of changes 
in species aptitude to vertical competition based on comprehensive climate-relationships is required.

\section{Acknowledgements}

The authors wish to thank the French Ministry for Agriculture and Fisheries for funding, the French forest service (ONF) for funding and making stem analyses data available, Daniel Rittié and Vincent Jédélé for conducting stem analyses. This article is dedicated to Marie-Claire Bontemps. 


\section{REFERENCES}

Albert, M. and Schmidt, M. 2010. Climate-sensitive modelling of site-productivity relationships for Norway spruce (Picea abies (L.) Karst.) and common beech (Fagus sylvatica L.). - Forest Ecology and Management 259: 739-749.

Bénichou, P. and Le Breton, P. 1987. Prise en compte de la topographie pour la cartographie des champs pluviométriques statistiques. - La Météorologie 7: 23-34.

Bergès, L. et al. 2005. Sessile oak (Quercus petraea Liebl.) site index variations in relation to climate, topography and soil in even-aged high-forest stands in northern France. - Annals of Forest Science 62: 391-402.

Boisvenue, C. and Running, S. W. 2006. Impacts of climate change on natural forest productivity evidence since the middle of the 20th century. - Global Change Biology 12: 862-882.

Bontemps, J.-D. et al. 2009. Long-term changes in forest productivity: a consistent assessment in even-aged stands. - Forest Science 55: 549-564.

Bontemps, J.-D. et al. 2011. Nitrogen footprint in a long-term observation of forest growth over the twentieth century. - Trees 25: 237-251.

Bugmann, H. 1996. Functional types of trees in temperate and boreal forests: classification and testing. - Journal of Vegetation Science 7: 359-370.

Charru, M. et al. 2010. Recent changes in forest productivity: An analysis of national forest inventory data for common beech (Fagus sylvatica L.) in north-eastern France. - Forest Ecology and Management 260: 864-874.

Cook, E. R. and Kairiukstis, L. A. (eds.). 1990. Methods of dendrochronology. - Kluwer Academic Publishers.

Croisé, L. et al. 2005. Two independent methods for mapping bulk deposition in France. Atmospheric Environment 39: 3923-3941. 
Curtis, R. O. 1964. A stem analysis approach to site index curves. - Forest Science 10: 241-256.

Dhôte, J.-F. and Hervé, J.-C. 2000. Productivity changes in four Sessile Oak forests since 1930: a stand-level approach (in French). - Annals of Forest Science 57: 651-680.

Diaz-Maroto, I. et al. 2006. Autecology of sessile oak (Quercus petraea) in the north-west Iberian Peninsula. - Scandinavian Journal of Forest Research 61: 458-469.

Dittmar, C. et al. 2003. Growth variations of Common beech (Fagus sylvatica L.) under different climatic and environmental conditions in Europe - a dendroecological study. - Forest Ecology and Management 173: 63-78.

Duplat, P. and Tran-Ha, M. 1997. Modélisation de la croissance en hauteur dominante du chêne sessile (Quercus petraea Liebl) en France. Variabilité inter-régionale et effet de la période récente (1959-1993). - Annals of Forest Science 54: 611-634.

Elfving, B. and Tegnhammar, L. 1996. Trends of tree growth in Swedish forests 1953-1992: an analysis based on sample trees from the National Forest Inventory. - Scandinavian Journal of Forest Research 11: 26-37.

Falster, D. S. and Westoby, M. 2003. Plant height and evolutionnary games. - Trends in Ecology and Evolution 18: 337-343.

Garcia, O. 1989. Forest modelling - new developments. - In: Nagumo, H. and Konohira, Y. (eds.), Japan and New Zealand symposium on forestry management planning. - Japan Association for Forestry Statistics, pp. 152-158.

Garcia, O. 2006. Site index: concepts and methods. - In: Cieszewski, C. J. and Strub, M. (eds.), Second International Conference on Forest Measurements and Quantitative Methods and Management, pp. 275-283.

Hansen, U. et al. 2002. Variation of pigment composition and antioxidative systems along the canopy light gradient in a mixed beech/oak forest: a comparative study on deciduous tree species differing in shade tolerance. - Trees 16: 354-364. 
Holland, E. A. et al. 2005. Nitrogen deposition onto the United States and Western Europe: synthesis of observations and models. - Ecological Applications 15: 38-57.

Hüffel, G. 1926. Les méthodes de l'aménagement forestier en France. - Berger-Levrault.

IFN. 2010. The French forest. Results from national annual inventories 2005-2009. - IFN.

IPCC. 2007. Climate Change 2007: The Physical Science Basis. Contribution of Working Group I to the Fourth Assessment Report of the Intergovernmental Panel on Climate Change. - Cambridge University Press.

Jones, P. D. and Moberg, A. 2003. Hemispheric and Large-Scale Surface Air Temperature Variations: An Extensive Revision and an Update to 2001. - Journal of Climate 16: 206-223.

Jump, A. S. et al. 2006. Rapid climate change-related growth decline at the southern range edge of Fagus sylvatica. - Global Change Biology 12: 2163-2174.

Kahle, H. P. et al. 2008. Temporal trends and spatial patterns of height growth changes in relation to changes in air temperature and precipitation, and in relation to levels of foliar nitrogen and nitrogen deposition. - In: Causes and consequences of forest growth trends in Europe. EFI, pp. 127-167.

Keeling, C. D. et al. 1986. Daily averaged concentrations of atmospheric carbon dioxide at fixed land stations and from air collection over the oceans. - Inst. Oceanogr., La Jolla, California, $259 \mathrm{pp}$.

King, D. A. 1990. The adaptive significance of tree height. - American Naturalist 135: 809-828.

Kiviste, A. 1999. Site index change in the 1950s-1990s according to Estonian forest inventory data. - In: EFI (ed.) Causes and consequences of accelerating tree growth in Europe, pp. 87-100.

Koeble, R. and Seufert, G. 2003. Novel maps for forest tree species in Europe. 2nd CarboEurope Whole Cluster Meeting, p. 6.

Lanner, R. M. 1985. On the insensitivity of height growth to spacing. - Forest Ecology and Management 13: 143-148. 
Lebourgeois, F. 2006. Climate sensitivity of sessile and pedunculate oaks in the RENECOFOR network. Comparison to beech stands (in French). - Revue Forestière Française 53: 29-43.

Lebourgeois, F. et al. 2004. Climate-tree-growth relationships of Quercus petraea Mill. stand in the Forest of Bercé ("Futaie des Clos", Sarthe, France). - Annals of Forest Science 61: 361-372.

Lebourgeois, F. et al. 2005. Climate-tree-growth relationships of European beech (Fagus sylvatica L.) in the French Permanent Plot Network (RENECOFOR). - Trees 19: 385-401.

Lévy, G. et al. 1992. A comparison of the ecology of pedunculate and sessile oaks: radial growth in the centre and northwest of France. - Forest Ecology and Management 55: 51-63.

Lindström, M. J. and Bates, D. M. 1990. Nonlinear mixed effect models for repeated measures data. - Biometrics 46: 673-687.

Messaoud, Y. and Chen, H. Y. H. 2011. The Influence of Recent Climate Change on Tree Height Growth Differs with Species and Spatial Environment. - PLoS one 6: 8 p., doi:10.1371/journal.pone.0014691.

Morneau, F. et al. 2008. Mixed forests in metropolitan France. An assessment based on National Forest Inventory results (in French). - Revue Forestière Française 60: 107-120.

Nathan, R. et al. 2001. Field validation and sensitivity analysis of a mechanistic model for tree seed dispersal by wind. - Ecology 82: 374-388.

Piedallu, C. and Gégout, J.-C. 2007. Multiscale computation of solar radiation for predictive vegetation modelling. - Annals of Forest Science 64: 899-909.

Pienaar, L. V. and Shiver, B. D. 1984. The effect of planting density on dominant height in unthinned slash pine plantations. - Forest Science 30: 1059-1066.

Pierrat, J.-C. et al. 1995. Estimation of the average of highest values in a finite population: application to forest inventories (in French). - Biometrics 51: 679-686. 
Pinheiro, J. C. and Bates, D. M. 2000. Mixed-effects models in S and S-PLUS. - Springer-Verlag.

Piovesan, G. et al. 2008. Drought-driven growth reduction in old beech (Fagus sylvatica L.) forests of the central Appenines, Italy. - Global Change Biology 14: 1-17.

Rennolls, K. 1978. "Top height"; its definition and estimation. - Commonwealth Forestry Review 57: 215-219.

Seynave, I. et al. 2008. Is the spatial distribution of European beech (Fagus sylvatica L.) limited by its potential height growth? - Journal of Biogeography 35: 1851-1862.

Skovsgaard, J.-P. and Vanclay, J. K. 2008. Forest site productivity: a review of the evolution of dendrometric concepts for even-aged stands. - Forestry 81: 13-31.

Solberg, S. et al. 2009. Analyses of the impact of changes in atmospheric deposition and climate on forest growth in European monitoring plots: A stand growth approach. - Forest Ecology and Management 258: 1735-1750.

Spiecker, H. et al. (eds.). 1996. Growth trends in European forests. - Springer-Verlag.

Turc, L. 1961. Estimation of irrigation water requirements, potential evapotranspiration : a simple climatic formula evolved up to date. - Annals of Agronomy 12: 13-49.

Visser, H. and Molenaar, J. 1990. Estimating trends in tree-Ring data. - Forest Science 36: 87-100.

Watt, M. S. et al. 2010. Development of models to predict Pinus radiata productivity throughout New Zealand. - Canadian Journal of Forest Research 40: 488-499.

Zeide, B. 1993. Analysis of growth equations. - Forest Science 39: 594-616. 


\begin{tabular}{|c|c|c|c|c|c|c|}
\hline Sample & 01 & B1 & $\mathbf{O 2}$ & B2 & $\mathbf{O 3}$ & 04 \\
\hline \multicolumn{7}{|l|}{ Sampling design } \\
\hline number of forests & 6 & 9 & 9 & 12 & 5 & 4 \\
\hline number of plot-pairs & 10 & 15 & 10 & 14 & 10 & 9 \\
\hline within-pair distance (m) & $\begin{array}{c}370 \\
(290)\end{array}$ & $\begin{array}{c}3700 \\
(2540)\end{array}$ & $\begin{array}{c}210 \\
(310)\end{array}$ & $\begin{array}{l}160 \\
(80)\end{array}$ & $\begin{array}{c}375 \\
(270)\end{array}$ & $\begin{array}{c}390 \\
(290)\end{array}$ \\
\hline mean age of younger stands (yrs) & $\begin{array}{c}79.8 \\
(22.3)\end{array}$ & $\begin{array}{c}76.9 \\
(26.2)\end{array}$ & $\begin{array}{l}71.5 \\
(24.2)\end{array}$ & $\begin{array}{c}64.6 \\
(15.0)\end{array}$ & $\begin{array}{c}89.7 \\
(27.5)\end{array}$ & $\begin{array}{c}98.9 \\
(17.8)\end{array}$ \\
\hline mean age of older stands (yrs) & $\begin{array}{l}152.8 \\
(22.4)\end{array}$ & $\begin{array}{l}150.4 \\
(23.6)\end{array}$ & $\begin{array}{l}146.6 \\
(31.4)\end{array}$ & $\begin{array}{l}140.1 \\
(20.2)\end{array}$ & $\begin{array}{l}167.0 \\
(37.3)\end{array}$ & $\begin{array}{l}171.7 \\
(22.8)\end{array}$ \\
\hline \multicolumn{7}{|l|}{ Height increments } \\
\hline sample size & 212 & 390 & 220 & 356 & 224 & 189 \\
\hline mean annual increment $\left(\mathrm{cm} \cdot \mathrm{yr}^{-1}\right)$ & $\begin{array}{c}28.1 \\
(12.8)\end{array}$ & $\begin{array}{c}32.3 \\
(13.8)\end{array}$ & $\begin{array}{c}30.1 \\
(14.5)\end{array}$ & $\begin{array}{c}36.9 \\
(13.5)\end{array}$ & $\begin{array}{c}26.7 \\
(10.9)\end{array}$ & $\begin{array}{c}25.8 \\
(10.3)\end{array}$ \\
\hline mean timespan (yrs) & $\begin{array}{c}9.3 \\
(4.1)\end{array}$ & $\begin{array}{c}8.3 \\
(4.7)\end{array}$ & $\begin{array}{c}8.4 \\
(4.6)\end{array}$ & $\begin{array}{c}7.2 \\
(3.9)\end{array}$ & $\begin{array}{c}9.7 \\
(4.5)\end{array}$ & $\begin{array}{l}10.0 \\
(4.3)\end{array}$ \\
\hline \multicolumn{7}{|l|}{ Site conditions } \\
\hline mean elevation (m a.s.1.) & $\begin{array}{l}240 \\
(40)\end{array}$ & $\begin{array}{l}125 \\
(50)\end{array}$ & $\begin{array}{l}305 \\
(60)\end{array}$ & $\begin{array}{l}370 \\
(50)\end{array}$ & $\begin{array}{l}120 \\
(15)\end{array}$ & $\begin{array}{l}265 \\
(20)\end{array}$ \\
\hline \multicolumn{7}{|l|}{ Temperatures } \\
\hline mean annual temperature $\left(\mathrm{Tm},{ }^{\circ} \mathrm{C}\right)$ & $\begin{array}{l}10.0 \\
(0.2)\end{array}$ & $\begin{array}{l}10.0 \\
(0.4)\end{array}$ & $\begin{array}{c}9.3 \\
(0.3)\end{array}$ & $\begin{array}{c}9.0 \\
(0.1)\end{array}$ & $\begin{array}{l}10.8 \\
(0.3)\end{array}$ & $\begin{array}{l}10.5 \\
(0.1)\end{array}$ \\
\hline $\begin{array}{l}\text { growing season mean temperature }\left({ }^{\circ} \mathrm{C}\right) \\
\text { (April-September) }\end{array}$ & $\begin{array}{l}14.3 \\
(0.2)\end{array}$ & $\begin{array}{l}14.2 \\
(0.6)\end{array}$ & $\begin{array}{l}14.6 \\
(0.4)\end{array}$ & $\begin{array}{l}14.2 \\
(0.2)\end{array}$ & $\begin{array}{l}15.3 \\
(0.4)\end{array}$ & $\begin{array}{l}15.3 \\
(0.2)\end{array}$ \\
\hline \multicolumn{7}{|l|}{ Water resources } \\
\hline annual precipitation $(\mathrm{P}, \mathrm{mm})$ & $\begin{array}{l}806 \\
(33)\end{array}$ & $\begin{array}{l}786 \\
(95)\end{array}$ & $\begin{array}{l}847 \\
(90)\end{array}$ & $\begin{array}{l}928 \\
(61)\end{array}$ & $\begin{array}{l}684 \\
(24)\end{array}$ & $\begin{array}{l}788 \\
(24)\end{array}$ \\
\hline annual water balance (P-PET, $\mathrm{mm})$ & $\begin{array}{l}148 \\
(36)\end{array}$ & $\begin{array}{c}144 \\
(111)\end{array}$ & $\begin{array}{l}195 \\
(99)\end{array}$ & $\begin{array}{l}300 \\
(58)\end{array}$ & $\begin{array}{l}-30 \\
(19)\end{array}$ & $\begin{array}{l}67 \\
(30)\end{array}$ \\
\hline soil water capacity (SWC, mm) & $\begin{array}{l}168 \\
(10)\end{array}$ & $\begin{array}{l}126 \\
(41)\end{array}$ & $\begin{array}{l}138 \\
(50)\end{array}$ & $\begin{array}{l}136 \\
(37)\end{array}$ & $\begin{array}{l}150 \\
(26)\end{array}$ & $\begin{array}{l}122 \\
(26)\end{array}$ \\
\hline soil water deficit - end August (mm) & $\begin{array}{l}16 \\
(8)\end{array}$ & $\begin{array}{l}41 \\
(10)\end{array}$ & $\begin{array}{c}6 \\
(7)\end{array}$ & $\begin{array}{l}15 \\
(12)\end{array}$ & $\begin{array}{l}34 \\
(7)\end{array}$ & $\begin{array}{l}18 \\
(6)\end{array}$ \\
\hline \multicolumn{7}{|l|}{ Nutritional resources (30 cm depth) } \\
\hline soil pH & $\begin{array}{c}4.1 \\
(0.25)\end{array}$ & $\begin{array}{l}4.3 \\
(0.8)\end{array}$ & $\begin{array}{c}4.5 \\
(0.35)\end{array}$ & $\begin{array}{c}5.0 \\
(0.9)\end{array}$ & $\begin{array}{l}4.3 \\
(0.3)\end{array}$ & $\begin{array}{c}4.5 \\
(0.45)\end{array}$ \\
\hline soil base saturation rate $(\mathrm{BS}, \%)$ & $\begin{array}{c}22 \\
(17)\end{array}$ & $\begin{array}{l}34 \\
(23)\end{array}$ & $\begin{array}{l}36 \\
(20)\end{array}$ & $\begin{array}{l}47 \\
(34)\end{array}$ & $\begin{array}{l}35 \\
(20)\end{array}$ & $\begin{array}{l}33 \\
(27)\end{array}$ \\
\hline soil $\mathrm{C}: \mathrm{N}$ ratio & $\begin{array}{l}22.8 \\
(5.7)\end{array}$ & $\begin{array}{l}17.5 \\
(2.9)\end{array}$ & $\begin{array}{l}16.5 \\
(3.1)\end{array}$ & $\begin{array}{l}16.2 \\
(2.8)\end{array}$ & $\begin{array}{l}21.2 \\
(3.5)\end{array}$ & $\begin{array}{l}18.6 \\
(1.0)\end{array}$ \\
\hline soil phosphorus content $\left(\mathrm{g} \cdot \mathrm{kg}^{-1}\right)$ & $\begin{array}{c}0.13 \\
(0.07)\end{array}$ & $\begin{array}{c}0.16 \\
(0.12)\end{array}$ & $\begin{array}{c}0.18 \\
(0.08)\end{array}$ & $\begin{array}{c}0.23 \\
(0.29)\end{array}$ & $\begin{array}{c}0.10 \\
(0.07)\end{array}$ & $\begin{array}{c}0.06 \\
(0.02)\end{array}$ \\
\hline
\end{tabular}

Table 1. Main characteristics of sessile oak $(\mathrm{O})$ and common beech samples $(\mathrm{B})$. See figure 1 for sample location. For each sample and indicator, standard-deviations are given under parentheses. 


\begin{tabular}{|c|c|c|c|c|c|c|c|}
\hline \multirow[b]{2}{*}{ Sample } & \multicolumn{5}{|c|}{$\begin{array}{l}\text { Growth equation (AP equation) })^{\mathbf{a}, \mathbf{b}} \\
\mathrm{S}_{\mathrm{b}} f_{1}\left(H_{0}\right)=d H_{0} / d t=\mathrm{S}_{\mathrm{b}}\left(H_{0} / \mathrm{K}_{\mathrm{S}}\right)^{\mathrm{m} 1 \mathrm{~m} 2} /\left(1-\mathrm{m} 1+\mathrm{m} 1\left(H_{0} / \mathrm{K}_{\mathrm{S}}\right)^{\mathrm{m} 2}\right)\end{array}$} & \multicolumn{2}{|c|}{$\begin{array}{l}\text { Residual variance function } \\
\mathrm{V}(\varepsilon)^{2}=\sigma^{2}\left(t-t_{-1}\right)^{2 \delta}\end{array}$} \\
\hline & $\begin{array}{c}\mathbf{S}_{\mathbf{b}}{ }^{\mathbf{c}} \\
\left(\mathrm{m} \cdot \mathrm{yr}^{-1}\right)\end{array}$ & $\begin{array}{l}\mathbf{K}_{\mathbf{S}} \\
(\mathrm{m})\end{array}$ & $\begin{array}{c}\text { m1 } \\
-\end{array}$ & $\begin{array}{c}\mathbf{m} 2 \\
-\end{array}$ & $\begin{array}{c}\sigma_{\mathrm{S}} \\
\left(\mathrm{m} \cdot \mathrm{yr}^{-1}\right)\end{array}$ & $\begin{array}{c}\sigma \\
\left(\mathrm{m} \cdot \mathrm{yr}^{-\delta}\right)\end{array}$ & \\
\hline 01 & $\begin{array}{l}0.417 \\
(0.027)\end{array}$ & $\begin{array}{c}6.1 \\
(0.9)\end{array}$ & $\begin{array}{l}0.138 \\
(0.096)\end{array}$ & $\begin{array}{c}2.36 \\
(0.13)\end{array}$ & 0.052 & $\begin{array}{l}0.243 \\
(0.147)\end{array}$ & $\begin{array}{c}0.242 \\
(0.320)\end{array}$ \\
\hline O2 & $\begin{array}{c}0.380 \\
(0.034)\end{array}$ & $\begin{array}{c}3.0 \\
(0.5)\end{array}$ & $\begin{array}{l}0.008 \\
(0.003)\end{array}$ & $\begin{array}{c}2.73 \\
(0.19)\end{array}$ & 0.071 & $\begin{array}{l}0.477 \\
(0.097)\end{array}$ & $\begin{array}{c}0.159 \\
(0.200)\end{array}$ \\
\hline $\mathbf{O 3}$ & $\begin{array}{c}0.336 \\
(0.018)\end{array}$ & $\begin{array}{c}5.6 \\
(1.4)\end{array}$ & $\begin{array}{l}0.047 \\
(0.050)\end{array}$ & $\begin{array}{c}2.42 \\
(0.25)\end{array}$ & 0.022 & $\begin{array}{l}0.183 \\
(0.118)\end{array}$ & $\begin{array}{c}0.286 \\
(0.264)\end{array}$ \\
\hline 04 & $\begin{array}{l}0.313 \\
(0.022)\end{array}$ & $\begin{array}{c}6.9 \\
(0.05)\end{array}$ & $\begin{array}{l}0.087 \\
(0.076)\end{array}$ & $\begin{array}{c}2.45 \\
(0.24)\end{array}$ & 0.041 & $\begin{array}{l}0.810 \\
(0.137)\end{array}$ & $\begin{array}{l}0.065 \\
(0.311)\end{array}$ \\
\hline
\end{tabular}

\begin{tabular}{|c|c|c|c|c|c|c|c|c|c|}
\hline \multirow[b]{2}{*}{ Sample } & \multicolumn{9}{|c|}{$\begin{array}{l}\text { Effect of date (cubic spline, internode } 20 \text { years) } \\
f_{2}(t)=1+\mathrm{d}_{1} t+\mathrm{d}_{2} t^{2}+\mathrm{d}_{3} t^{3}+\sum_{\mathrm{k}=1}^{4} \mathrm{p}_{\mathrm{k}} \max (t-20 \mathrm{k}, 0)^{3}+\sum_{\mathrm{k}=0}^{1} \mathrm{pm}_{\mathrm{k}} \min (t+20 \mathrm{k}, 0)^{3}\end{array}$} \\
\hline & $\begin{array}{c}\mathrm{d}_{\mathbf{1}} \mathbf{x} \mathbf{1 0}^{\mathbf{2}} \\
\left(\mathrm{yr}^{-1}\right)\end{array}$ & $\begin{array}{c}\mathbf{d}_{\mathbf{2}} \mathbf{x} \mathbf{1 0}^{\mathbf{3}} \\
\left(\mathrm{yr}^{-2}\right)\end{array}$ & $\begin{array}{c}\mathbf{d}_{\mathbf{3}} \times \mathbf{1 0}^{\mathbf{4}} \\
\left(\mathrm{yr}^{-3}\right)\end{array}$ & $\begin{array}{c}\mathbf{p}_{\mathbf{1}} \times \mathbf{1 0}^{\mathbf{4}} \\
\left(\mathrm{yr}^{-3}\right)\end{array}$ & $\mathbf{p}_{2}$ & $\mathbf{p}_{3}$ & $\mathbf{p}_{4}$ & $\mathbf{p m}_{0}$ & $\mathrm{pm}_{1}$ \\
\hline O1 & $\begin{array}{l}0.201 \\
(0.263)\end{array}$ & $\begin{array}{l}0.027 \\
(0.347)\end{array}$ & $\begin{array}{l}-0.063 \\
(0.115)\end{array}$ & $\begin{array}{l}0.284 \\
(0.233)\end{array}$ & $\begin{array}{l}-0.622 \\
(0.254)\end{array}$ & $\begin{array}{l}1.076 \\
(0.317)\end{array}$ & $\begin{array}{l}-1.545 \\
(0.687)\end{array}$ & $\begin{array}{l}0.084 \\
(0.208)\end{array}$ & $\begin{array}{l}-0.076 \\
(0.150)\end{array}$ \\
\hline $\mathbf{O 2}$ & $\begin{array}{l}-0.027 \\
(0.340)\end{array}$ & $\begin{array}{l}0.553 \\
(0.449)\end{array}$ & $\begin{array}{l}-0.176 \\
(0.158)\end{array}$ & $\begin{array}{l}0.444 \\
(0.310)\end{array}$ & $\begin{array}{l}-0.673 \\
(0.318)\end{array}$ & $\begin{array}{c}1.009 \\
(0.380)\end{array}$ & $\begin{array}{l}-1.706 \\
(0.765)\end{array}$ & $\begin{array}{l}0.329 \\
(0.289)\end{array}$ & $\begin{array}{l}-0.183 \\
(0.201)\end{array}$ \\
\hline $\mathbf{O 3}$ & $\begin{array}{l}0.913 \\
(0.254)\end{array}$ & $\begin{array}{l}0.162 \\
(0.291)\end{array}$ & $\begin{array}{l}-0.197 \\
(0.109)\end{array}$ & $\begin{array}{l}0.647 \\
(0.230)\end{array}$ & $\begin{array}{l}-0.938 \\
(0.257)\end{array}$ & $\begin{array}{c}0.813 \\
(0.317)\end{array}$ & $\begin{array}{l}-0.291 \\
(0.667)\end{array}$ & $\begin{array}{l}0.212 \\
(0.173)\end{array}$ & $\begin{array}{l}-0.013 \\
(0.081)\end{array}$ \\
\hline O4 & $\begin{array}{c}0.954 \\
(0.305)\end{array}$ & $\begin{array}{l}0.478 \\
(0.398)\end{array}$ & $\begin{array}{l}-0.239 \\
(0.131)\end{array}$ & $\begin{array}{l}0.585 \\
(0.260)\end{array}$ & $\begin{array}{l}-0.647 \\
(0.283)\end{array}$ & $\begin{array}{c}0.554 \\
(0.374)\end{array}$ & $\begin{array}{l}-0.770 \\
(0.895)\end{array}$ & $\begin{array}{l}0.284 \\
(0.231)\end{array}$ & $\begin{array}{l}-0.029 \\
(0.153)\end{array}$ \\
\hline
\end{tabular}

Table 2. Parameter estimates and their standard-errors for height growth models fitted on sessile oak data. Standard-errors of parameters in parentheses. ${ }^{a}$ See Eq. 1, ${ }^{\mathrm{b}}$ see Eq. 3, ${ }^{\mathrm{c}}$ estimated mean of parameter $S_{b}$. 


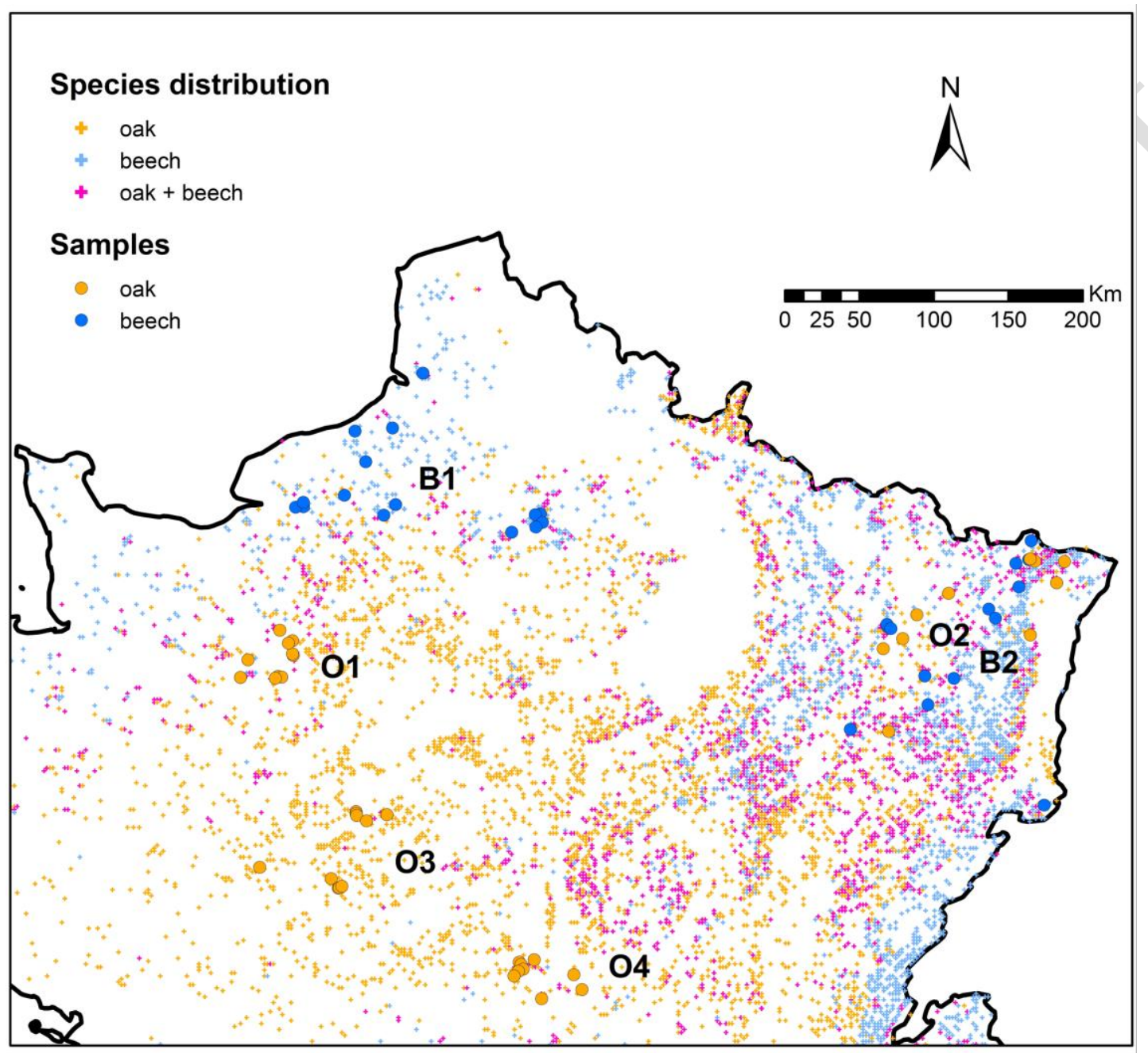

Figure 1. Spatial distribution of common beech and sessile oak tree species in northern France and location of regional samples. Distribution data (National Forest Inventory grid at 2-km resolution) distinguish between forest plots where occurrences in only one species are found and those where they are observed jointly. Sample data: each circle correspond to a pair of old/young pure and even-aged stands, O1 to O4: sessile oak samples, B1 and B2: common beech samples. 


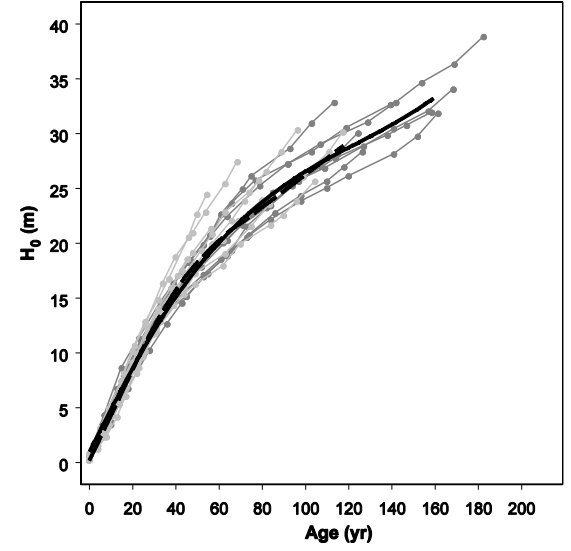

$\mathrm{O} 3$

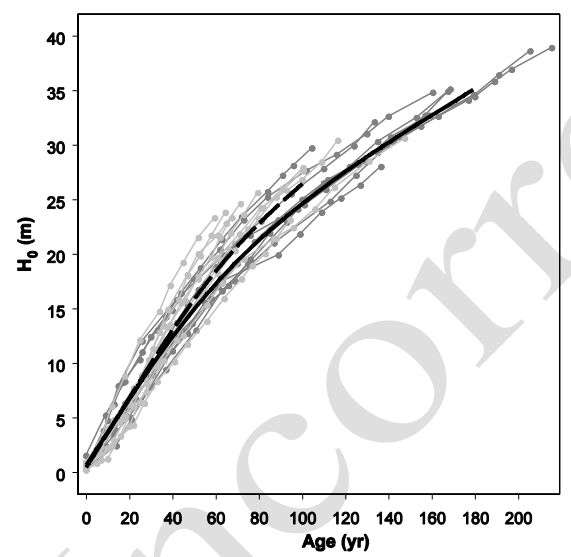

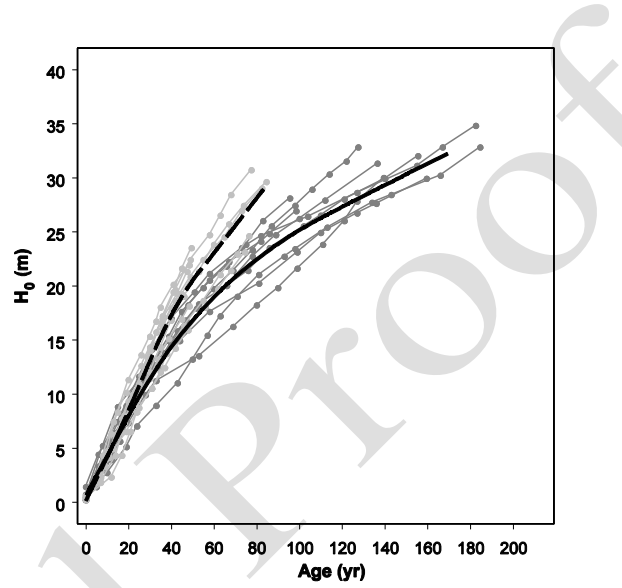

$\mathrm{O} 4$

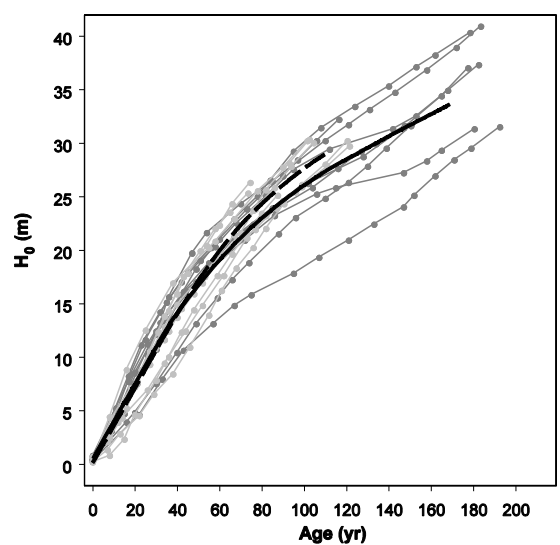

Figure 2. Patterns of top height growth in sessile oak and between-generation comparison. Dashed lines: older stands, full lines: younger stands. Light grey: individual curves, dark grey: average curves over older (dashed) and younger (full) stands. Top left: O1, top right O2, bottom left: O3, bottom right: $\mathrm{O} 4$. 


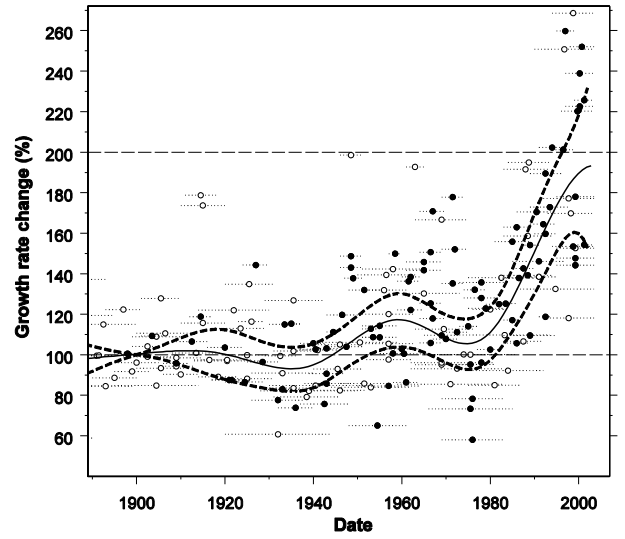

$\mathrm{O} 3$

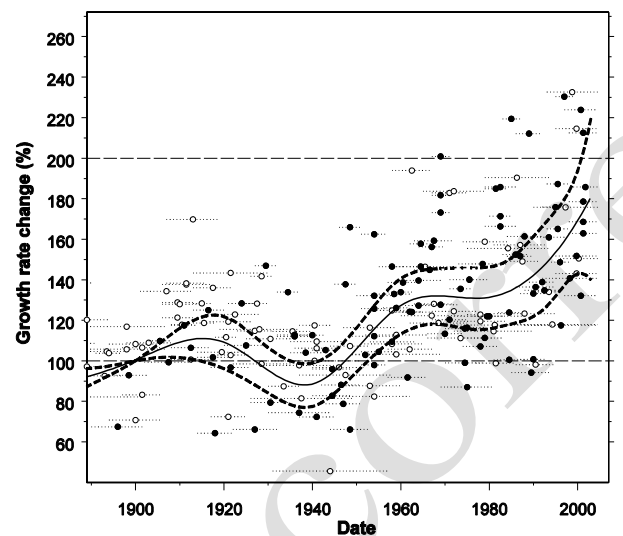

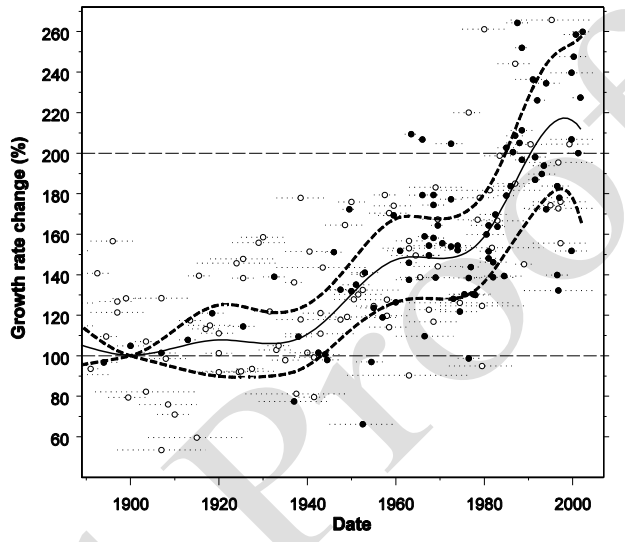

$\mathrm{O} 4$

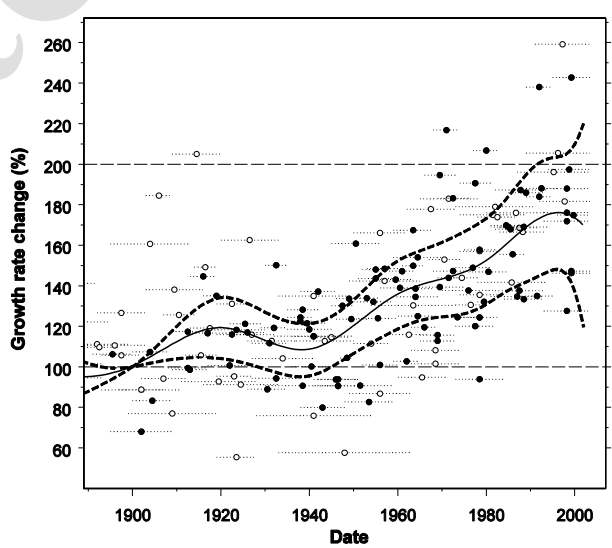

Figure 3. Relative historical changes in top height growth rate of sessile oak. The reference year is 1900 (reference level of 1). The relative scale expresses a change relative to that period. Full line: mean chronology estimate, dashed lines: 95\% bilateral confidence interval. Full/empty circles: younger/older stand increments. Horizontal dashed intervals: increment time spans. Top left: O1, top right $\mathrm{O} 2$, bottom left: $\mathrm{O} 3$, bottom right: $\mathrm{O} 4$. 

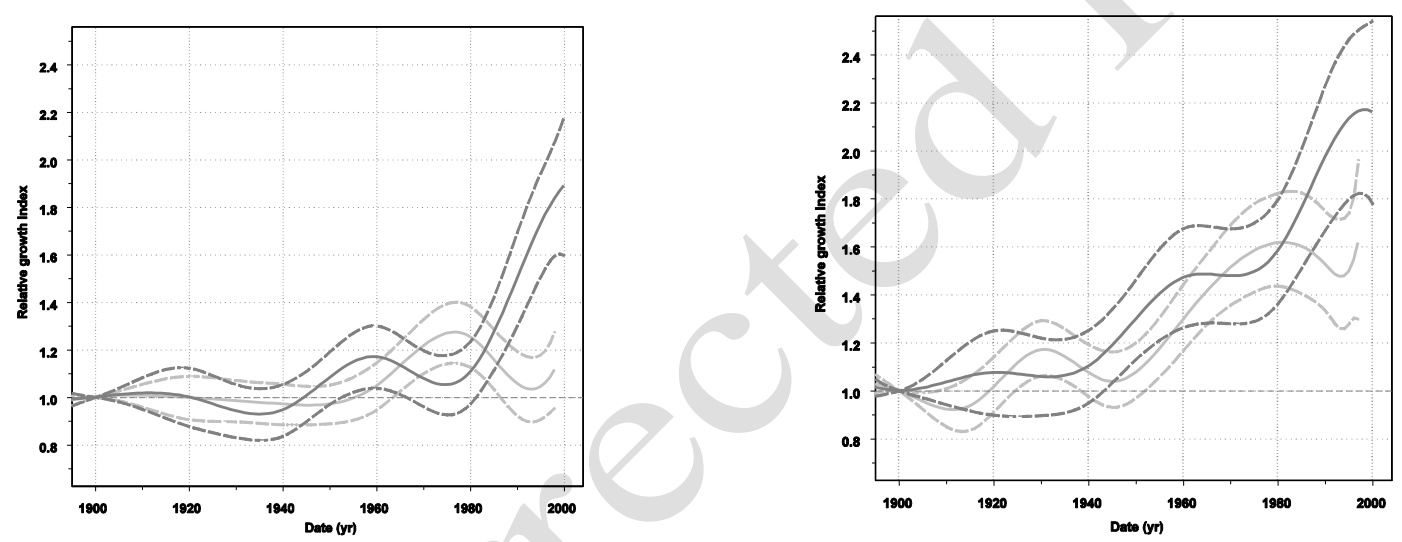

Figure 4. Comparison of relative historical changes in top height growth of sessile oak and common beech in northern samples. Left: O1/B1 - north-western France, right: O2/B2 - northeastern France. Dark grey: sessile oak. Light grey: common beech. Dashed lines: 95\% bilateral confidence intervals. Chronologies from common beech arise from Bontemps et al. 2011. 

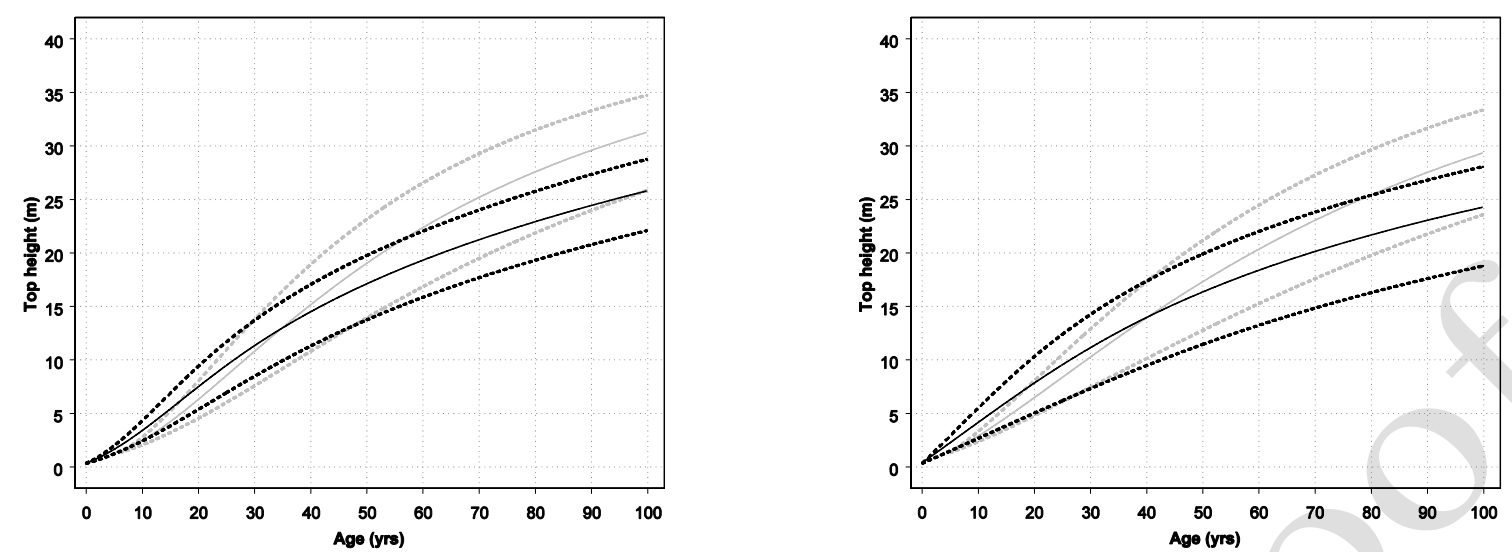

b
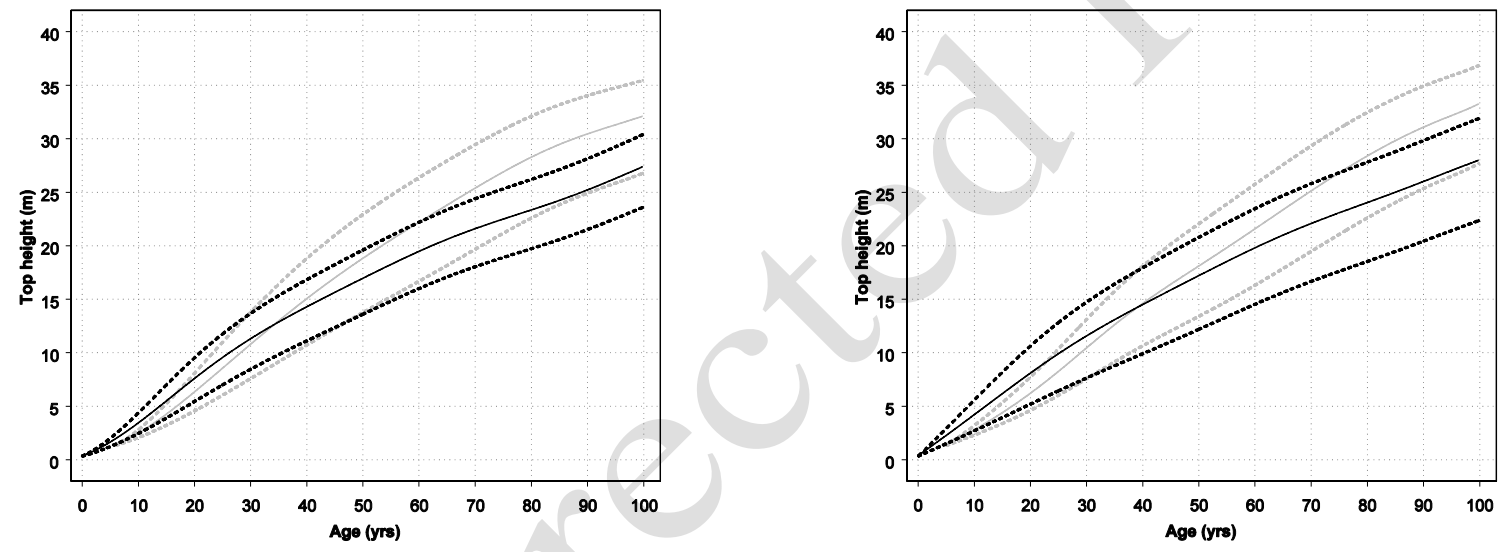

c
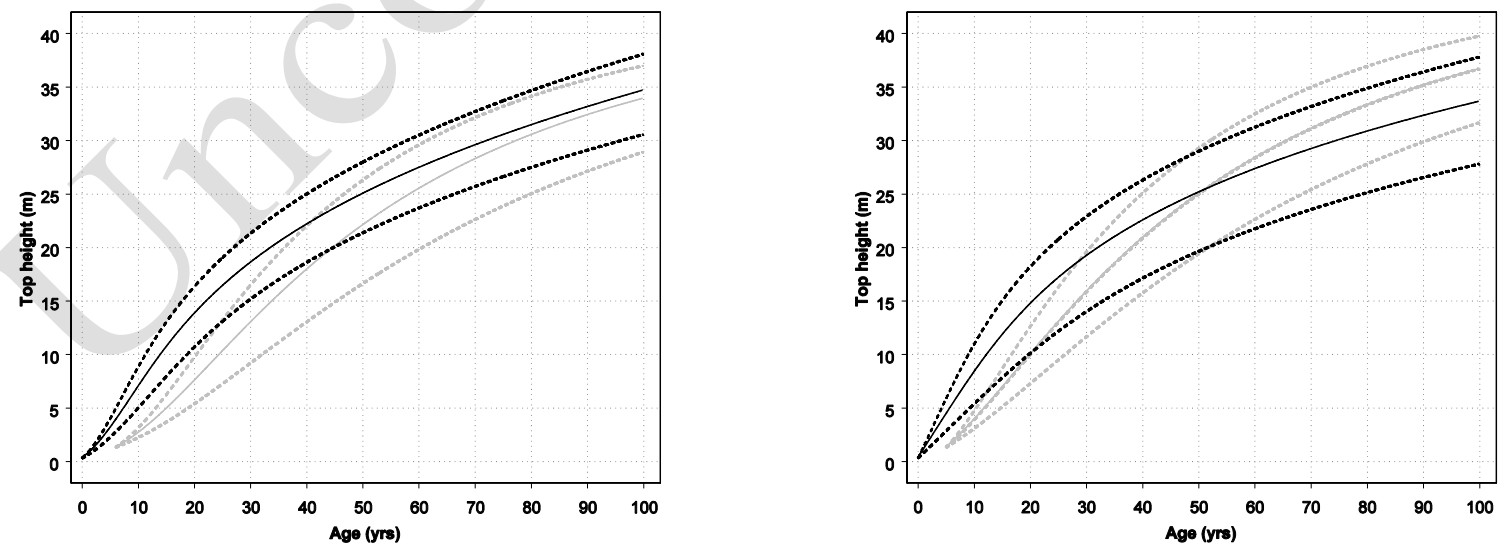

Figure 5. Compared trajectories of top height growth in common beech and sessile oak at different dates. Left: O1/B1, right: O2/B2. a: virtual permanent conditions of 1900, b: progressive shift over the $20^{\text {th }}$ century, c: virtual permanent conditions of 2000. Dark grey: sessile oak. Light grey: common beech. 


\section{Supplementary material}

\section{Appendix 1}

Figure A1. Annual 20th-century chronologies of (a) mean temperature and (b) precipitation anomalies for samples O1/B1, O2/B2 and 02/O3. These chronologies were computed from 12 precipitation and 11 temperature homogenised climatic series produced by Météo-France (Moisselin et al. 2002).

a
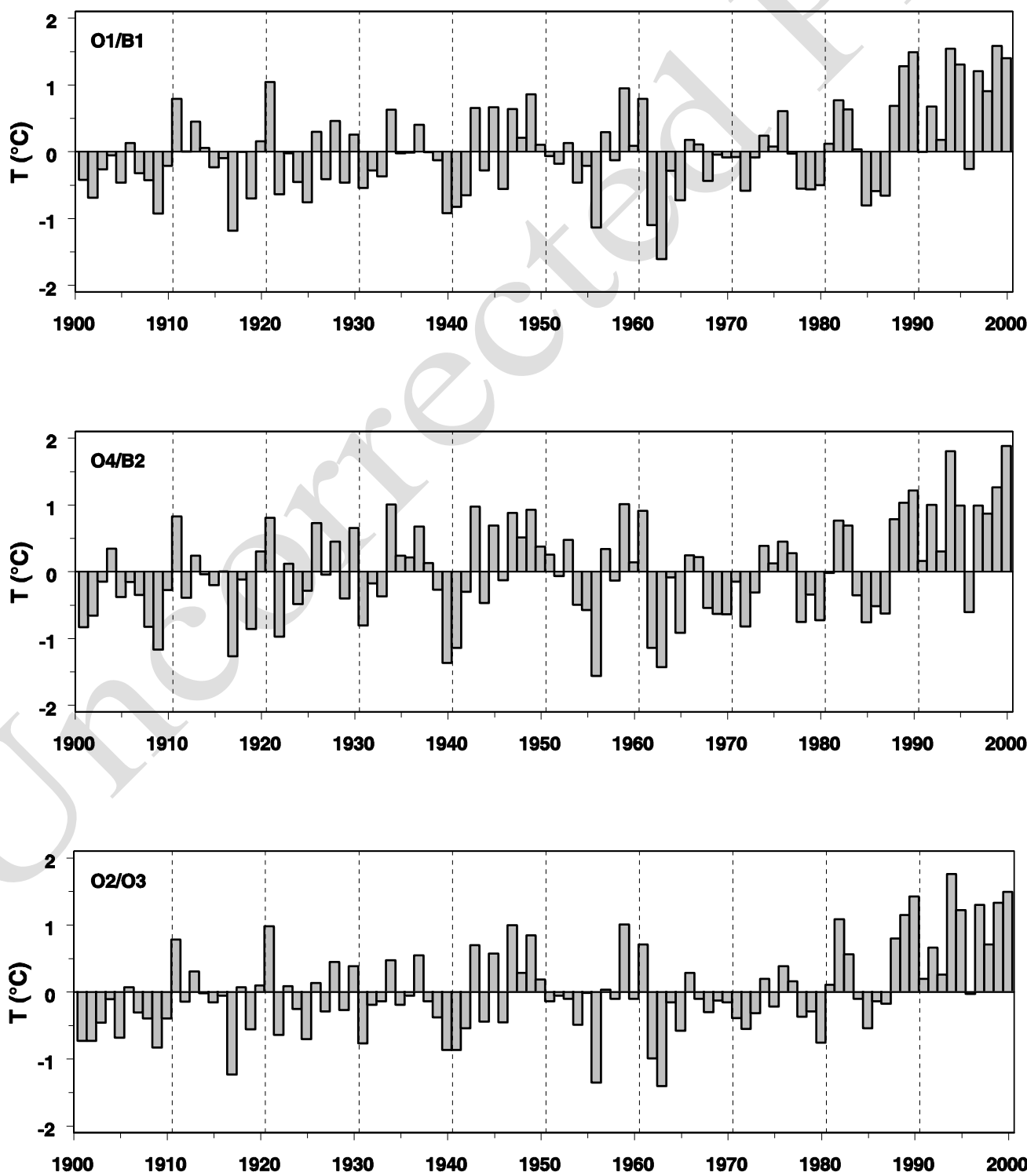

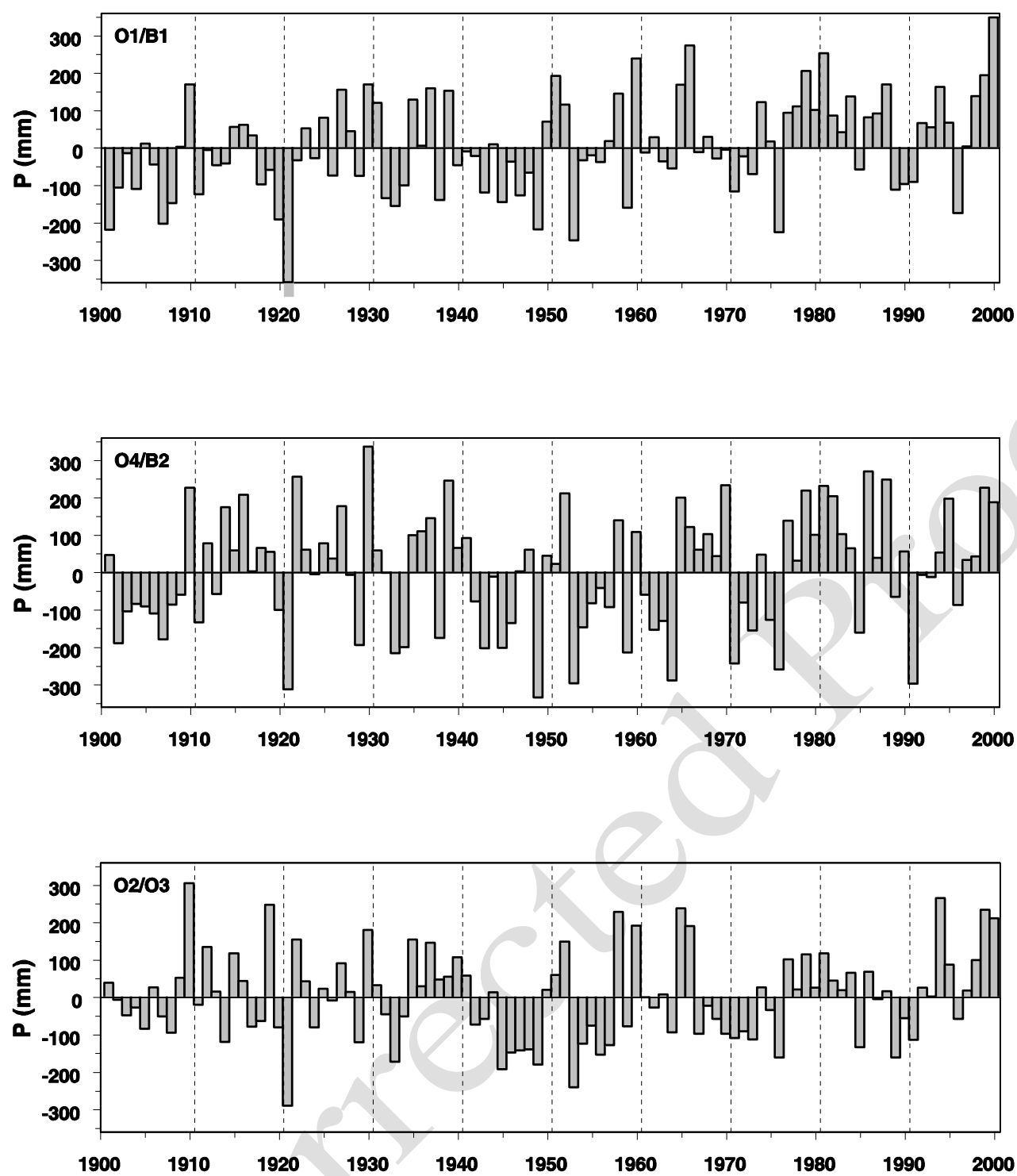


\section{Appendix 2. Growth equations tested to model the effect of ontogenetic stage on growth in sessile oak}

These growth equations (Korf equation, and an original equation termed "AP equation", see article) are presented in the traditional form of an autonomous differential equation: $d X / d t=f(X)$, where $f$ corresponds to $f_{1}$ in the present modelling approach (see Eq. 1 in the article):

$$
\text { Korf: } \quad \mathrm{S}_{\mathrm{b}} f_{1}\left(H_{0}\right)=\mathrm{S}_{\mathrm{b}}\left(H_{0} / \mathrm{K}\right)\left(\ln \left(\mathrm{K} / H_{0}\right)\right)^{1+\mathrm{m}} \mathrm{C}_{\mathrm{m}}
$$

where $H_{0}$ is top height, $\mathrm{S}_{\mathrm{b}}$ is the maximal growth rate $(\mathrm{m} / \mathrm{year}), \mathrm{K}$ is the height asymptote $(\mathrm{m}), \mathrm{m}$ is a shape parameter (dimensionless), and $\mathrm{C}_{\mathrm{m}}$ is a constant depending on $\mathrm{m}: \mathrm{Cm}=\exp [(1+\mathrm{m})(1-\ln$ $(1+\mathrm{m}))]$,

$$
A P: \quad \mathrm{S}_{\mathrm{b}} f_{1}\left(H_{0}\right)=\mathrm{S}_{\mathrm{b}}\left(H_{0} / \mathrm{K}_{\mathrm{S}}\right)^{\mathrm{m} 1 \mathrm{~m} 2} /\left[1-\mathrm{m} 1+\mathrm{m} 1\left(H_{0} / \mathrm{K}_{\mathrm{S}}\right)^{\mathrm{m} 2}\right]
$$

where $K_{S}$ is the height $(m)$ at which $S_{b}$ is attained (inflection point), and $m 1 / m 2$ are 2 shape parameters with $\mathrm{m} 1<1$ and $0<\mathrm{m} 1, \mathrm{~m} 2$. When $t>>1$, we have: $H_{0}(t) \sim\left(\mathrm{C} \mathrm{S}_{\mathrm{b}} t\right)^{\alpha}$ where $\alpha=(1+\mathrm{m} 2$ $(1-\mathrm{m} 1))^{-1}<1$ (hence height is an inverse-parabolic branch of time), and $\mathrm{C}$ is a constant depending on $\mathrm{K}_{\mathrm{s}}, \mathrm{m} 1$ and $\mathrm{m} 2$.

\section{Appendix 3. Statistical modelling steps for sessile oak}

We first compared the Korf and AP equation accuracies by fitting each equation over the data for each sessile oak sample separately, without any effect of calendar year, and introducing a betweenstand pair variation in parameter $S_{b}$, which was significant (coefficient of variation of ca. 8 to $20 \%$ depending on the sample). The AP equation showed a significantly higher accuracy than the Korf equation in all samples ( $p<10^{-4}$, with a minimum -10.0 AIC units). The introduction of the $f_{2}$ cubic spline function of time with a 20 years internode was found very significant in all samples $\left(p<10^{-}\right.$ $\left.{ }^{4}\right)$. However, the refined 15 and 10-years internodes did not improve the fits. Heteroskedasticity was identified in the residuals. A general residual variance function, expressed as a power function of the increment time interval, was tested, and was very significant in samples $\mathrm{O} 2$ and $\mathrm{O} 3\left(p<10^{-4}\right)$ and at the limit of significance in samples O1 and O4 $(p=0.1)$. We again compared the Korf and AP equations, by testing the Korf equation in the latter model structure. The AP equation remained significantly more accurate than the Korf equation ( -3 to -6 AIC units, $p=0.04$ to 0.02 ). on parameters $\mathrm{K}_{\mathrm{S}}, \mathrm{m} 1$, and $\mathrm{m} 2 . \mathrm{S}_{\mathrm{b}}$ was identified with the site fertility parameter in Eq. 1.

\section{Reference list}

Moisselin, J. M., Schneider, M., Canellas, C. and Mestre, O. 2002. Les changements climatiques en France au XXe siècle. Etude des longues séries homogénéisées de données de température et de précipitations. - La Météorologie 38: 45-56. 